\title{
Comparing the personality of three well-known sporting brands in Iran
}

\author{
Mohmood Mohammadian* and Hamidreza Asgari Dehabadi
}

${ }^{e}$ Department of Management and Accounting, Allameh Tabataba'i University,Tehran, Iran

\begin{tabular}{l}
\hline A R T I C L E I N F O \\
\hline Article history: \\
Received December 15, 2011 \\
Received in Revised form \\
February, 14, 2011 \\
Accepted 24 March 2012 \\
Available online \\
April 14 2012 \\
\hline Keywords: \\
Brand Personality \\
Sincerity \\
Excitement \\
Sophisticated \\
Competence \\
Ruggedness
\end{tabular}
\begin{abstract}
A B S T R A C T
A significant amount of literature specifies that there are benefits for having a favorable brand personality, such as purchase intentions and enhanced brand attitudes and higher degrees of consumer trust and loyalty. Brand differentiation is one of most important issues to handle competition in the hostile marketplace. A reliable solution for establishing the distinctiveness of a brand is through brand personality. This study analyzes the personality of Adidas, Nike and Puma brands in Iran using Aaker,s brand personality dimensions [Aakar (1997). Dimensions of brand personality. Journal of Marketing Resources, 24, 347-356]. First, data are collected using a questionnaire designed based on Aaker,s model. Second, the K-S and Friedman tests are done to analyze the collected data. Results indicate that in terms of sincerity and competence, Adidas scores are higher than two other brands. Nike in point of view of excitement, and Puma in terms of sophisticated and ruggedness dimensions have higher position in comparison to other brands.
\end{abstract}

\section{Introduction}

Brands have a history that goes back to long before the development of modern marketing. Brands should be understood as an institutional embodiment of the logic of a new form of informational capital - much like the factory embodied the logic of industrial capital. Brand management is a matter of putting to work the capacity of consumers and increasingly other kinds of actors to create a common social world through autonomous processes of communication and interaction. This capacity to produce a common social world is empowered and programmed to unfold in ways, which create the measurable kinds of attention, which underpin the commercial values of brands.

Brand management involves the adaptation of a brand to changes in the market and to maintain the meaning of a brand, adjustments in brand positioning does not have to affect the perceived essence of a brand. Ideally, such adjustments reinforce the meaning of a brand, and shed new light on existing brand features (Keller, 2003). Brand managers are normally facing the challenge of adapting their

* Corresponding author. Tel.: +989198032661

E-mail addresses: hamid.askari66@gmail.com (M. Mohammadian)

(C) 2012 Growing Science Ltd. All rights reserved.

doi: $10.5267 / \mathrm{j} . \mathrm{msl} .2012 .04 .008$ 
brands without diluting its essence. This is not easy, as illustrated by the introduction of Harley Davidson fragrances, which alienated loyal customers who could not link fragrances to Harley's core features of ruggedness and masculinity (Haig, 2003).

One of the most important motivations for applying brand management to a consumer product or service is considered as competition. As the number of similar products or services in the marketplace increases, we need for more differentiated brands and with a rise in competition, there is often a similar rise in the speed of measuring brand performance in the marketplace. In an information-rich environment, impatient retailers usually discard brands, which do not deliver consistent and profitable sales. The same is considered for the survival of a television network or program in an everincreasing competitive environment.

Brands are symbols around including firms, suppliers, supplementary organizations, the public, customers and even nations construct. Branding is a critical issue in international marketing because brands permit actors, such as organizations, individuals and indeed countries to express their opinions in foreign markets in different ways, where even language does not convey. Brands have been the focus of significant focus in the international marketing literature, where researchers have addressed such issues as the differences between international and local brands (e.g. Schuiling \& Kapferer, 2004), global brand equity (Hsieh, 2004), and international brand counterfeiting (Green \& Smith, 2004; Gillespie, Krishna, \& Jarvis, 2002).

Today, Adidas, Nike and Puma are well-known brands in Iran and these brands were selected for this study since they are considered as important sporting brands in Iran. Consistently superior quality, continuing innovation, and value-for-money products emerging out of the advanced technology employed, have enabled these brands to be as 'The Most Trusted Brand' in sporting goods in Iran.

There is a lack of research in the Iranian context specifically exploring the applicability of Jennifer Aaker's Brand Personality Scale on sporting goods. Nevertheless, the competition in many industries has intensified with the globalization and import of foreign goods in Iran. Hence, building of brands plays an important role for competing firms. In such a scenario, systematic research aimed at measuring and validating the Jennifer Aaker's Brand Personality Scale is of utmost importance for brand managers and advertising agencies.

\section{Theoretical background}

The work of Aaker (1997) inspired the majority of the research on brand personality to date. She meticulously developed a 44-item Brand Personality Scale, which encompasses five broad dimensions: Sincerity, Excitement, Competence, Sophistication, and Ruggedness. The scale has served as a brand personality measure in many studies, and its factor structure proved to be robust in many of these studies (Aaker, 1997, 1999; Aaker et al., 2001; Kim et al., 2001). However, Aaker's scale has recently been criticized on several grounds. The first one is associated with weak definition of brand personality, which includes several other characteristics such as age, gender, etc. in addition to personality (Azoulay \& Kapferer, 2003; Bosnjak, Bochmann, \&Hufschmidt, 2007). This induces a construct validity problem and leaves researchers and practitioners uncertain of what they have actually measured: the perceived brand personality (a sender aspect) or perceived user characteristics (receiver aspects).

The other vital issue is related to non-generalizability of the factor structure to investigate the respondent level for a specific brand or within a particular product category (Austin et al., 2003). Since Aaker (1997) performed all analyses on information gathered across respondents for betweenbrand comparisons and removed all within-brand variance, which led to factor analysis results exclusively based on between-brand variance. As a result, the framework does not appear to 
generalize to situations in which analyses are requested at the individual brand level and/or situations in which consumers are elements of differentiation.

Another issue was associated with the non-replicability of the five factors cross-culturally (Azoulay \& Kapferer, 2003). For example, Aaker et al. (2001) reported that only three of the five factors used in Spain namely, Sincerity, Excitement, and Sophistication. This shortcoming led several researchers to construct a country-specific brand personality scale. Bosnjak et al. (2007) developed a German scale, Milas and Mlačić(2007) a Croatian one, and van den Berge, and Franzen (2002) a Dutch one.

For many years, the concept of brand personality was considered as marketing practice (Olins1978). Years of anecdotal, practical accounts in the business press lauding the virtues of brand personality stimulated a groundswell of academic interest in the topic. The concept has been developed since then and it has continued to be as one of the contemporary marketing theory and practice today. Recently, it has been investigated in another contexts such as financial services (e.g., Gibbons, 2008) and biotechnology (e.g., Papania et al. 2008), as well as across genders (e.g., Grohmann 2009) and attachment types (Swaminathan et al. 2009).

During the last two decades, many people have interested in the concept of brand personality in two concepts: brand characteristics and human personality. Acceptance of the lexical approach to human personality (De Raad, 2000) as an important branch of personality psychology has resulted in the emergence of the Big-Five model of personality description (Goldberg, 1993). Due to its comprehensiveness, the Big-Five is often conceived as an integrative framework in personality research (Goldberg \& Rosolack, 1994). After Aaker's (1997) seminal paper, which identified the brand personality dimensions of Sincerity, Excitement, Competence, Sophistication and Ruggedness, a new way of conceiving the brand personality construct, with the Big-Five human personality as a metaphor, began to appear. A study by Caprara et al. (2001), which examined the brand personality of 12 mass-market brands in the Italian market, which uses a measure developed from Roman Italian personality taxonomy (Caprara \& Perugini, 1994), is a specific interest to the present study. Caprara et al. (2001) first used a measure in the field of brand personality and demonstrated that a five-factor structure cannot be replicated when we use to describe brands. Advertising expenditures linked to brand-building activities look to disappear over the years (Mela et al., 1997; Neslin, 2002; Srinivasan et al., 2004). This evolving allocation of resources across marketing activities has posed a problem with regard to the return on marketing investments.

To evaluate the return on marketing investments, companies could use sales or profits, but they also might turn to several other equities such as relational, brand, customer (Seggie et al., 2007). This issue raises the question of the most effective strategy for mixing consumer promotions and brandbuilding activities. Consumers implement brand personality dimensions to identify the brand's added value. Brand personality ensured a stable brand image over time (Aaker, 1996) and permits consumers to show their own personalities (Aaker, 1997). Brand personality also affects consumer attitudes towards the brand (Wysong, 2000). Although no evidence is associated with brand personality dimensions directly to brand equity, various studies have explored the effects of brand personality on elements, which reflect components of brand equity. For instance, brand personality influences brand preferences (Kim, 2000), brand attachment (Sung et al., 2005), brand trust (Hess et al., 2007), and brand loyalty (Brakus et al., 2009).

Aaker (1999) showed that people tend to select and use brands with aspects of their own personality in different situational contexts. Especially for high self-monitoring individuals (highly prone to social cues), her results explain that traits made accessible by situational cues may influence consumer's brand choice and that different traits that are made salient, can have different effects on brand attitudes based on the brand's personality. besides, more recent investigation on the relationship between brands and people (Aaker et al., 2004) demonstrated that brand personality traits could 
directly influence on the way the relationship between brand and owner was formed and maintained. Aaker et al. (2004) explained that in line with implications of the brand personality concept, relationships with sincere brands deepen over time, whereas consumer-brand relationships for exciting brands show a more short-lived, "fling-like" development over time.

Many researchers have stressed the importance of building a strong brand personality, which refers "to the set of human characteristics associated with a brand" (Aaker, 1997). Although a number of studies have studied how consumers form and update their brand personality impressions (Aaker et al., 2004; Johar et al., 2005), systematic work examined how employees influence brand personalities has been limited.

\subsection{Dimensions of brand personality}

To examine how the relationship between brand and human personality may drive preference, Aaker (1997) explained that two types of brand personality scales could be implemented. The first one is associated with ad hoc scales, typically consists of a set of traits ranging from 20 to 300 in number. These scales do not tend to be theoretical in nature and they are often developed for the purposes of a specific research study. In addition, the traits, which are selected often are chosen arbitrarily, which casts doubt upon the scales' reliability and validity. The second type of brand personality scales are those that are more theoretical in nature, but are based on human personality scales, which have not been validated in the context of brands (e.g., Bellenger et al., 1976; Dolich, 1969). Some dimensions (or factors) of human personality may be mirrored in brands whilst others might not. In Fig. 1, the Jennifer Aaker's brand personality model is indicated.

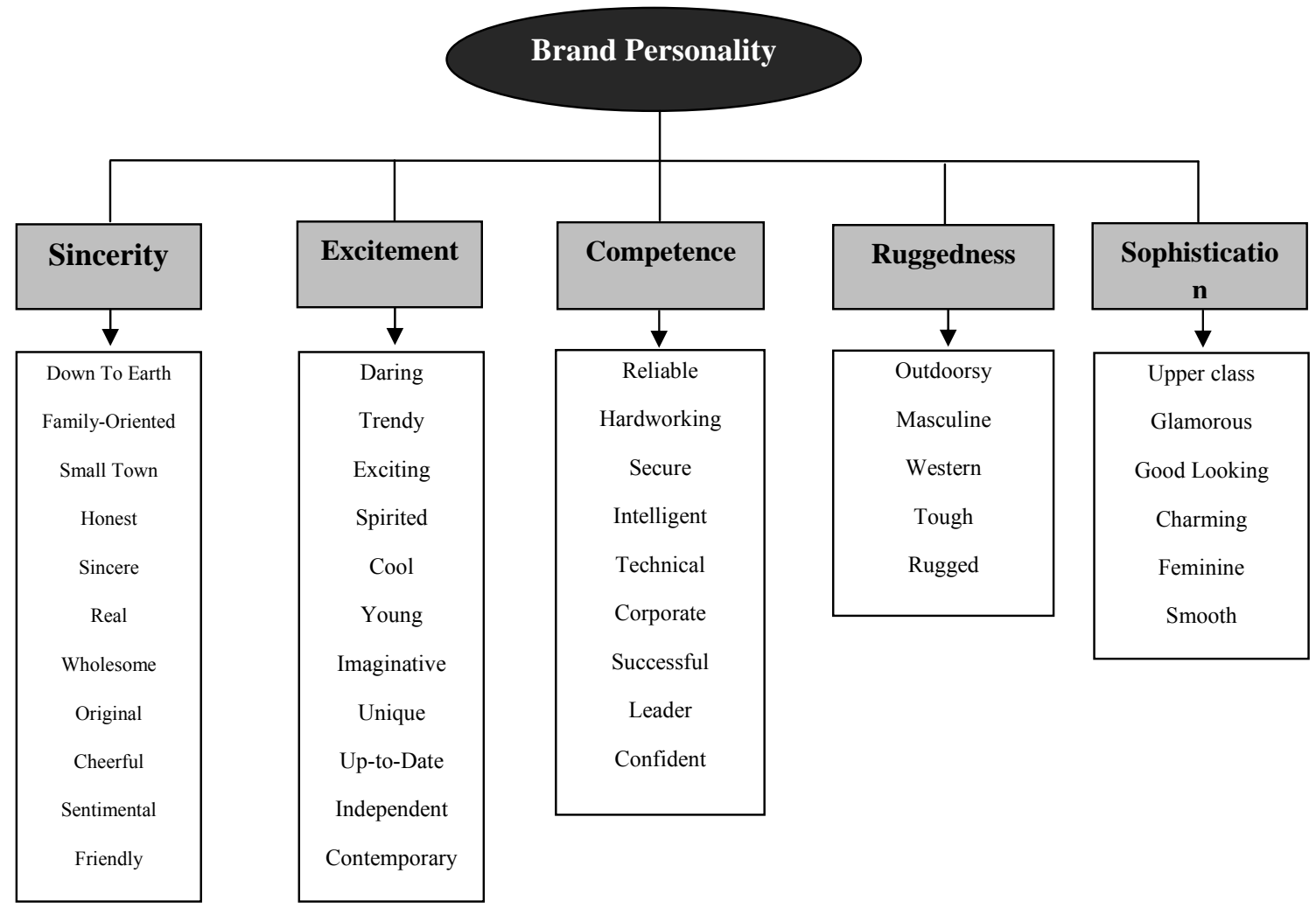

Fig.1. The Jennifer Aaker's Brand Personality Model

\section{Methodology}

The population for this study consists of all the peoples who use sporting goods in Iran. The sample for the study was selected from the population by simple random sampling method. A structured questionnaire was prepared based on Aaker's Dimensions of Brand Personality. The questionnaire 
comprises of two parts: The first part of the questionnaire contains 3 questions on demographic factors of users such as age, gender, and level of respondents' educational background. The second part of the questionnaire contains 42 questions, which are associated with 42 traits corresponding to the 5 brand personality dimensions, viz., Sincerity (down-to-earth, family-oriented, small-town, honest, sincere, realistic, wholesome, original, cheerful, sentimental, friendly), Excitement (contemporary, independent, up-to-date, unique, imaginative, young, cool, spirited, exciting, trendy, daring), Competence (reliable, hard-working, secure, intelligent, technical, corporate, successful, leader, confident), Sophistication (upper-class, glamorous, good-looking, charming, feminine, smooth) and Ruggedness (outdoorsy, masculine, western, tough, rugged).

\subsection{Multidimensional model of brand personality with structural equation model}

The path diagram illustrates the multidimensional model of the brand personality of three sporting brands. The brand personality is the exogenous variable and the brand personality dimensions namely sincerity, excitement, competence, sophistication and ruggedness are endogenous variables, i.e., brand personality causes the brand personality dimensions.

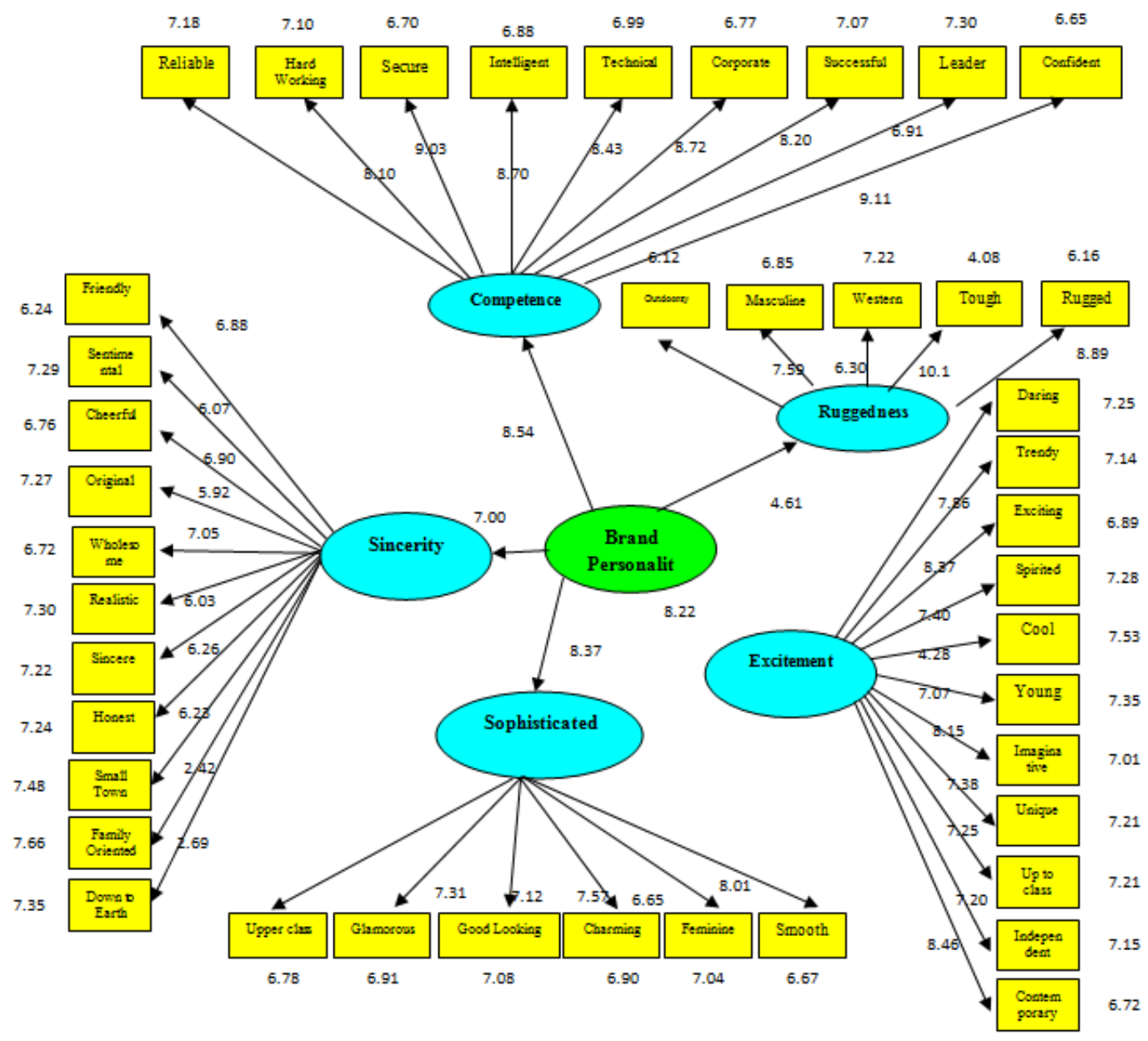

Fig. 2. Path Diagram of Brand Personality

Variables such as competence, ruggedness, sophisticated, excitement and sincerity are latent variables. These latent variables are measured by their subcategory variables. Fig. 2 Indicates the path diagram of Aaker's brand personality model. This path diagram is depicted by LISREL software. This diagram is used to measure the model validity. In this way, the validity of model is indicated by 
a series of indicators. Table 1 indicates these indicators and their allowable extent and exhibits the results of structural equation model conducted for the 42 brand personality items.

\section{Table 1}

Indexes of goodness of fit

\begin{tabular}{lll}
\hline & Value & allowable extent \\
\hline $\mathrm{Chi}^{2} / d f$ & 2.154 & 3 and down \\
GFI & 0.9 & 0.9 and up \\
RMSEA & 0.099 & 0.1 and down \\
CFI & 0.93 & 0.9 and up \\
AGFI & 0.83 & 0.8 and up \\
NFI & 0.9 & 0.9 and up \\
NNFI & 0.93 & 0.9 and up \\
\hline
\end{tabular}

Generally, these indicators alone cannot be used for model validity acceptance; thus, we should to have in minds all of these indicators and then interpret the results. Results of Table1 indicate that Aaker's brand personality model has sufficient validity; thus, we can use this model for our research.

\section{Data analysis and results}

This research includes 5 hypotheses about the personality of each three brands. These hypotheses are:

$\mathrm{H}_{1}$ : From the point of view of sincerity, Adidas is higher than two other brands.

$\mathrm{H}_{2}$ : From the point of view of excitement, Nike is higher than two other brands.

$\mathrm{H}_{3}$ : From the point of view of competence, Adidas is higher than two other brands.

$\mathrm{H}_{4}$ : From the point of view of ruggedness, Adidas is higher than two other brands.

$\mathrm{H}_{5}$ : From the point of view of sophisticated, Nike is higher than two other brands.

In the questioner, we used a 7-points semantic differential spectrum to measure the attitudes of respondents. The validity of questioner has been accepted using content validity method and the reliability of survey measured using Cronbach's alpha coefficient. This research uses the Kolomogorov-Smirnov test to confirm that the data have normal distribution and then, uses the Friedman method to test the hypothesis. About 77 percents of the respondents were male and 23 percents were female. Most of the respondents were undergraduates and the study indicated that about all of the respondents used Adidas, Nike or Puma products such as clothing, footwear, apparels and accessories. About 32.5 percents of respondents had Diploma degree, 40 percent had bachelor of science degree and 27.5 percents of them had master degree.

Table 2

Reliability and Equivalence of Various Items in Brand Personality Dimensions

\begin{tabular}{lccc}
\hline & No of Items & Cronbach Alpha & d.f \\
\hline Sincerity & 11 & .746 & 10 \\
Exciting & 11 & .888 & 10 \\
Competence & 9 & .926 & 8 \\
Sophistication & 6 & .818 & 5 \\
Ruggedness & 5 & .844 & 4 \\
\hline
\end{tabular}

From Table 2, sincerity, excitement, competence, sophistication and ruggedness dimensions achieved a high Cronbach's alpha coefficient, suggesting a high reliability and internal consistency. The Kolomogorov-Smirnov test is used to inform about the distribution of data in target populations. The hypothesis of this research noted that whether the target populations are homogenous. Our hypothesis in this section is: Do the target populations have normal distribution? The conclusion was that all of target populations ( 3 brands) do not have normal distribution. Table. 3 indicates the outputs of Kolomogorov-Smirnov test. 
Table 3

Asymp.Sig. (2-tailed) in Kolomogorov-Smirnov test (using SPSS software)

\begin{tabular}{|c|c|c|c|}
\hline & Adidas & Nike & Puma \\
\hline Down to Earth & .161 & .158 & .317 \\
\hline Family-oriented & .033 & .00 & .238 \\
\hline Small town & .474 & .689 & .586 \\
\hline Honest & .380 & .083 & .214 \\
\hline Sincere & .192 & .335 & .392 \\
\hline Real & .075 & .095 & .403 \\
\hline Wholesome & .125 & .108 & .147 \\
\hline Original & .323 & .225 & .229 \\
\hline Cheerful & .024 & .311 & .476 \\
\hline Sentimental & .392 & .081 & .332 \\
\hline Friendly & .160 & .074 & .127 \\
\hline Daring & .217 & .098 & .209 \\
\hline Trendy & .005 & .007 & .017 \\
\hline Exciting & .035 & .011 & .176 \\
\hline Spirited & .061 & .003 & .142 \\
\hline Cool & .038 & .048 & .392 \\
\hline Young & .016 & .020 & .234 \\
\hline Imaginative & .047 & .098 & .096 \\
\hline Unique & .084 & .176 & .243 \\
\hline Up-to-Date & .007 & .028 & .200 \\
\hline Independent & .068 & .0181 & .076 \\
\hline Contemporary & .074 & .129 & .115 \\
\hline Reliable & .015 & .131 & .204 \\
\hline Hardworking & .011 & .063 & .219 \\
\hline Secure & .025 & .044 & .134 \\
\hline Intelligent & .161 & .140 & .063 \\
\hline Technical & .053 & .233 & .058 \\
\hline Corporate & .065 & .067 & .055 \\
\hline Successful & .010 & .021 & .217 \\
\hline Leader & .006 & .070 & .219 \\
\hline Confident & .040 & .091 & .286 \\
\hline Upper class & .002 & .106 & .087 \\
\hline Glamorous & .009 & .209 & .072 \\
\hline Good looking & .001 & .012 & .179 \\
\hline Charming & .044 & .043 & .213 \\
\hline Feminine & .092 & .239 & .356 \\
\hline Smooth & .023 & .091 & .116 \\
\hline Outdoorsy & .005 & .302 & .104 \\
\hline Masculine & .030 & .136 & .065 \\
\hline Western & .023 & .069 & .076 \\
\hline Tough & .150 & .024 & .119 \\
\hline Rugged & .036 & .124 & .115 \\
\hline
\end{tabular}

$\mathrm{H}_{1}$ : From the point of view of sincerity, Adidas is higher than other brands.

For testing $\mathrm{H}_{1}$, we used Friedman test, where the test probes whether the columns of Table 3 are from one population. Table 4 indicates the results of Friedman test for $\mathrm{H}_{1}$ hypothesis.

Table 4

Friedman test for sincerity dimension

\begin{tabular}{lllllll}
\hline Sincerity & N & Min & Max & Mean & Mean Rank & s.d \\
\hline Adidas & 100 & 1 & 7 & 5.074 & 24.251 & 1.5678 \\
Nike & 100 & 1 & 7 & 4.806 & 18.809 & 1.6491 \\
Puma & 100 & 1 & 7 & 4.402 & 20.021 & 1.7090 \\
\hline
\end{tabular}


It is very obvious that the $\mathrm{H}_{1}$ hypothesis is accepted because the mean rank of Adidas brand in terms of sincerity is higher than Nike and Puma brands.

$\mathrm{H}_{2}$ : From the point of view of excitement, Nike is higher than other brands.

Table 5

Friedman test for excitement dimension

\begin{tabular}{lllllll}
\hline Excitement & $\mathrm{N}$ & Min & Max & Mean & Mean Rank & s.d \\
\hline Adidas & 100 & 1 & 7 & 7.653 & 24.251 & 1.303 \\
Nike & 100 & 1 & 7 & 5.538 & 25.780 & 1.254 \\
Puma & 100 & 1 & 7 & 4.908 & 23.855 & 1.520 \\
\hline
\end{tabular}

It is very obvious that the $\mathrm{H} 2$ hypothesis is accepted because the mean rank of Nike brand in terms of excitement is higher than Adidas and Puma brands.

H3: From the point of view of competence, Adidas is higher than two other brands.

Table 6

Friedman test for competence dimension

\begin{tabular}{lllllll}
\hline Sincerity & N & Min & Max & Mean & Mean Rank & s.d \\
\hline Adidas & 100 & 1 & 7 & 5.752 & 25.558 & 1.297 \\
Nike & 100 & 1 & 7 & 5.416 & 23.287 & 1.391 \\
Puma & 100 & 1 & 7 & 4.825 & 22.390 & 1.523 \\
\hline
\end{tabular}

It is very obvious that the $\mathrm{H} 3$ hypothesis is accepted because the mean rank of Adidas brand in terms of competence is higher than Nike and Puma brands.

H4: From the point of view of ruggedness, Adidas is higher than two other brands.

Table 7

Friedman test for ruggedness dimension

\begin{tabular}{lcccccc}
\hline Sincerity & N & Min & Max & Mean & Mean Rank & s.d \\
\hline Adidas & 100 & 1 & 7 & 5.697 & 24.604 & 1.350 \\
Nike & 100 & 1 & 7 & 5.295 & 23.820 & 1.210 \\
Puma & 100 & 1 & 7 & 5.220 & 25.724 & 1.543 \\
\hline
\end{tabular}

The mean rank of Puma is higher than other brands, therefore the H4 is not accepted. In the H4 argued that in terms of ruggedness, Adidas is higher than Nike and Puma.

H5: From the point of view of sophisticated, Nike is higher than two other brands.

\section{Table 8}

Friedman test for sophisticated dimension

\begin{tabular}{lcccccc}
\hline Sincerity & $\mathrm{N}$ & Min & Max & Mean & Mean Rank & s.d \\
\hline Adidas & 100 & 1 & 7 & 5.765 & 25.658 & 1.311 \\
Nike & 100 & 1 & 7 & 5.579 & 27.220 & 1.318 \\
Puma & 100 & 1 & 7 & 5.209 & 27.365 & 1.450 \\
\hline
\end{tabular}

Like former hypothesis, the mean rank of Puma is higher than other brands, therefore the H5 is not accepted. In the H5 argued that in terms of sophisticated, Nike is higher than Adidas and Puma.

\section{Discussion and implications}

The main objective of this research was to measure the brand personality dimensions of the Adidas, Nike and Puma brands using the Brand Personality Scale suggested by Aaker. The personal and demographic profile of the users indicated that majority of the users are young male in the early 
twenties or late twenties and belonged to the educated group. The analysis done by researchers indicated that the Adidas brand mainly communicated the brand personality dimension of "sincerity" and "competence", whilst Nike primarily conveyed the dimension of "excitement" and Puma portrayed a brand personality of "ruggedness" and "sophisticated".

The approach followed in the study described in this article can offer good general insights to marketing managers, international marketing managers, managers of distribution channels, sellers and purchasers of sporting goods in Iran despite the fact that it has concentrated specifically on how brand personality is shaped in the minds of customers. The approach can obviously be extended to other countries, but is equally applicable to other brands of products and services in the international environment. One of the best application of this research, in particular the used model and methodology of this survey, is that the conclusions of this research are applicable for designing appropriate marketing plans for this brands and then, efficiently implementing of these plans. The applicability of this scale to the Iranian situation was not checked because it required an exploratory study to identify the dimensions of brand personality in the Iranian situation.

\section{Acknowledgment}

The research study was financially assisted by a grant dedicated by Allameh Tabataba'i University and the authors would like to thank their efforts for their contributions. The authors are also grateful for constructive comments on earlier version of this work.

\section{References}

Aaker, J., Fournier, S., \& Brasel S.A.( 2004). When good brands do bad. Journal of Consumer Resources, 31(1), 1-16.

Aaker, J. (1997). Dimensions of brand personality. Journal of Marketing Resources, 24, 347-356.

Aaker, J., Benet-Martinez, V., \& Garolera, J. (2001). Consumption symbols as carriers of culture: a study of Japanese and Spanish brand personality constructs. Journal of personality and social psychology, 81, 492-508.

Arvidsson, A. (2006). Brands Meaning and Value in Media Culture. Taylor \& Francis e-Library.

Azoulay, A., \& Kapferer, J.N. (2003). Do brand personality scales really measure brand personality? Brand Management, 11, 143-155.

Brakus, J.J., Schmitt, B.H., \& Zarantonello, L. (2009). Brand experience: what is it? How is it measured? Does it affect loyalty? Journal of Marketing, 73(3), 52-68.

Caprara, G.V., \& Perugini, M. (1994). Personality described by adjectives: Generalizability of the Big Five to the Italian lexical context. European Journal of Personality, 357-69.

Caprara, G.V., Barbaranelli, C., \& Guido, G. (2001). Brand personality: how to make the metaphor fit? Journal of Econ Psychol, 2, 377-95.

De Raad, B. (2000). The Big Five Personality Factors: The Psycholexical Approach to Personality. Göttingen: Hogrefe and Huber Publishers.

Fennis, B.M., Pruyn, A. T. H. (2007). You are what you wear: Brand personality influences on consumer impression formation. Journal of Business Research, 60, 634-639.

Freling, T. H., Crosno, J.L., \& Henard, D.L. (2011). Brand personality appeal: conceptualization and empirical validation. Journal of the Academic Marketing Science, 39, 392-406.

Geuens, M., Weijters, B. \& De Wulf, K. (2009). A new measure of brand personality. International Journal of Research in Marketing, 26, 97-107

Gillespie, K., Krishna, K., \& Jarvis, S. (2002). Protecting global brands: Toward a global norm. Journal of International Marketing, 10(2), 99-113.

Gibbons, J. (2008). Discover your bank's personality. ABA Bank Marketing, 30-35.

Goldberg, L.R. (1993). The structure of phenotypic personality traits. American Psychologist, 48, $26-34$.

Goldberg, L.R., \& Rosolack, T.K. (1994). The Big-Five structure as an integrative framework.An empirical comparison with Eysenck's P-E-N model. In: Halverson CG, Kohnstamm GA, Martin RP, 
editors. The Developing Structure of Temperament and Personality from Infancy to Adulthood. New York, NY: Erlbaum. 7-35.

Green, R.T. \& Smith, T. (2004). Countering brand counterfeiters. Journal of International Marketing, 10(4), 89-106.

Grohmann, B. (2009). Gender dimensions of brand personality. Journal of Marketing Research, 46, 105119.

Haig, M. (2003). Brand Failures. London: Kogan Page.

Henderson, P.W., Cote, J. A., Leong, S.M., \& Schmitt, B. (2003). Building strong brands in Asia: selecting the visual components of image to maximize brand strength. International Journal of Research in Marketing, 20, 297-313.

Hess, S., Bauer, H., Kuester, S., \& Huber, F. (2007). In brands we trust: marketing's impact on service brand personality and trust. European Marketing Academy 36th Conference Proceedings. May: 22-25, Iceland.

Hosany, S., Ekinci, Y., \& Uysal, M. (2006). Destination image and destination personality: An application of branding theories to tourism places. Journal of Business Research, 59, 638-642.

Hsieh, M. H. (2004). Measuring global brand equity using cross-national survey data. Journal of International Marketing, 12(2), 28-57.

Keller, K. L. (1993). Conceptualizing, measuring and managing customer-based brand equity. Journal of Marketing, 57, 1-22.

Kim, H. (2000). Examination of brand personality and brand attitude within the apparel product category. Journal of Fashion Marketing Management, 4(3), 243-252.

Mela, C.F., Gupta, S., \& Lehmann, D.R. (1997). The long-term impact of promotion and advertising on consumer brand choice. Journal of Marketing Resources, 34(2), 248-261.

Milas, G., \& Mlačić, B. (2007). Brand personality and human personality: Findings from ratings of familiar Croatian brands. Journal of Business Research, 60, 620-626.

Pitta, L.F., Opokub, R., Hultmanb, M., Abrattc, R., \& Spyropouloud, S. (2007). What I say about myself: Communication of brand personality by African countries. Tourism Management, 28, 835-844.

Papania, L., Campbell, C., Opoku, R.A., Styven, M., \& Berthon, J.P. (2008). Using brand personality to assess whether biotechnology firms are saying the right things to their network. Journal of Commercial Biotechnology, 14, 247-255.

Malär, L. \& Nyffenegger, B., Krohmer, H., \& Hoyer, W.D. (2011). Implementing an intended brand personality: a dyadic perspective. Journal of the Academic Marketing Science. to appear.

Neslin, S. A. (2002). Sales Promotion. Cambridge. MA: Marketing Science Institute.

van Rekom, J., Jacobs, G., \& Verlegh, P.W.T. (2006). Measuring and managing the essence of a brand personality. Marketing Letters, 17, 181-192.

Schuiling, I., \& Kapferer, J. N. (2004). Real differences between local and international brands: Strategic implications for international marketers. Journal of International Marketing, 12(4), 97-112.

Seggie, S.H., Cavusgil, E., \& Phelan, S.E. (2007). Measurement of return on marketing investment: a conceptual framework and the future of marketing metrics. Industrial Marketing Management, 36(6), 834-841.

Srinivasan, S., Pauwels, K., Hanssens, D., \& Dekimpe, M. (2004). Do promotions benefit manufacturers, retailers, or both? Management Science, 50(5), 617-629.

Swaminathan, V., Stilley, K.M., \& Ahluwalia, R. (2009). When brand personality matters: the moderating role of attachment styles. Journal of Consumer Research, 35, 985-1002.

Sung, Y., \& Tinkham, S. (2005). Brand personality structures in the United States and Korea: common and culture-specific factors. J Cons Psych, 15(4), 334-50.

Valette-Florence, P., Guizani, H., \& Merunka, D. (2011). The impact of brand personality and sales promotions on brand equity. Journal of Business Research, 64, 24-28.

Wentzel, D. (2009). The effect of employee behavior on brand personality impressions and brand attitudes. Journal of the Academic Marketing Science, 37, 359-374.

Wysong, S. (2000). This brand's for you': a conceptualization and investigation of brand personality as process with implications for brand management. Doctoral Dissertation, University of Texas at Arlington. 